\title{
Between Tradition and Modernity: Wuzhen and China’s Soft Power in the 21st Century*
}

\author{
LIN Mao \\ History Department \\ Georgia Southern University, U.S.A.
}

\begin{abstract}
In recent years, Wuzhen, a Ming-Qing style water town located south of the Yangtze River, has quickly become one of the most popular tourist destinations in China. The success of Wuzhen was so influential that the term "Wuzhen Model” quickly became a buzzword in Chinese economic and cultural discourses. Promoters of Wuzhen have claimed that it embodies both tradition and modernity, therefore representing the best of China. While Wuzhen was first reconstructed as a "living museum" of Chinese cultural tradition to attract tourists, it increasingly started to claim itself as a leading “smart town” for China’s future development. Moreover, the so-called Wuzhen Model fits seamlessly into China's overall strategy of projecting its soft power both domestically and abroad. The purpose of this paper is to examine how Wuzhen was culturally constructed and how it helped to project China's soft power. It also examines how Wuzhen was perceived abroad, focusing primarily on major English-speaking countries including the United States, the United Kingdom, and Australia, to understand its impact on China's soft power.
\end{abstract}

Keywords: Wuzhen; Chinese soft power; tourism; modernity; Chinese foreign policy

"Wuzhen, an ancient small Chinese town with thousands of years of history, once again came into the limelight of the world." People's Daily, the biggest newspaper group in China and the paramount official newspaper of the Chinese Communist Party (CCP) proudly announced the opening of the Third World Internet Conference (WIC) in November 2016. ${ }^{1}$ The conference, jointly sponsored by the Cyberspace Administration of the People's Republic of China and the Zhejiang Provincial Government, first started in 2014 and chose Wuzhen as its permanent site. The juxtaposition of the Internet and a historic water town of China might appear odd, as visitors could be easily baffled by shop signs such as "Internet Tea Shop" or "Internet Hospital" hanging on traditional Ming-Qing style Chinese architecture. For promoters of Wuzhen and the WIC, however, the marriage between the two has been a happy one. What unified the couple was that Wuzhen became a perfect place to showcase China’s soft power. “Why does Wuzhen deserve to charm the world?” asked Global Times, another major newspaper in China: "Because the successful conclusion of the WIC was based on China's soft power" which originated from China's "correct handling of the relationship between freedom and order on the Internet."

${ }^{*}$ LIN Mao is an Assistant Professor of history at Georgia Southern University, U.S.A. His research focuses on diplomatic history of America and China. He can be reached at mlin@georgiasouthern.edu .

${ }^{1}$ Hongyan Wen, "Ran hulianwang genghao zaofu guojia he renmin" [Let the Internet Better Benefit the Country and the People], People’s Daily, November 15, 2016.

2 Xiaoyue Hu, “Zhongguo huliangwang shengzhangchu zhongguo ruanshili” [China’s Internet Grows China’s Soft Power], Global Times, December 15, 2015. 
While it is fair to say that the Wuzhen Summit, as the WIC was often called, marketed Wuzhen successfully, the opposite was also true. Before the idea of Wuzhen Summit was conceived, Wuzhen already had become one of the most popular tourist sites of China. That popularity, coupled with Wuzhen's decision to develop "smart tourism," was the key reason why it was chosen by the WIC. "When searching for the site of the WIC two years ago, experts wanted a place with a developed Internet economy and a rich traditional culture," the Zhejiang Provincial Government explained. "They looked for a town akin to Davos in Switzerland, home of the World Economic Forum, capable of embodying the meaning of the Internet. Wuzhen caught their eyes as Zhejiang, where the town is located, contains a great number of Internet users and websites.” For many, the very ancient look of the town made it perfect for today's world of the Internet. "The layout of Wuzhen, with waterways branching in all directions and more than 80 stone bridges, is identical with the concept of Internet-interconnection," the organizers of WIC boasted: "Held in a poetic town with bridges, flowing brooks and blue roofing tiles, the conference may gather nature, cultural tradition and modernity together."3

The claim that Wuzhen embodies both tradition and modernity is the focus of this paper. While Wuzhen was first reconstructed as a "living museum" of Chinese cultural tradition to attract tourists, it increasingly started to claim itself as a leading "smart town" for China's future development. Moreover, the so-called Wuzhen Model fits seamlessly into China's overall strategy of projecting its soft power both domestically and abroad. The purpose of this paper is to examine how Wuzhen was culturally constructed and how it helped to project China's soft power. It also examines how Wuzhen was perceived abroad, focusing primarily on major English-speaking countries including the United States, the United Kingdom, and Australia, to understand its impact on China's soft power.

\section{Soft Power, Culture, and Tourism in China: An Overview}

One of the most important developments of the post-Cold War international system is the rapid rise of China as a new global economic, military, and political powerhouse. This "Chinese miracle" first started when China initiated its "reform and opening up" in 1978 under Deng Xiaoping. Since then, China has transformed from a planned economy to a market-based economy, creating rapid economic and social changes. The Chinese economy has grown by an average rate of 10 percent over the past three decades, lifting more than 800 million people out of poverty. With a population of 1.3 billion, China now is the second largest economy and increasingly plays an influential role in the global economy. ${ }^{4}$ With its growing economic power, China has also increased its global political and cultural influence. The prestigious American-based Council on Foreign Relations put it bluntly, "China's steady rise in economic and political influence is the single event that will reshape international politics in the 21st century." $\mathrm{A}$ recent article in the influential journal The Atlantic marveled at the rapid rise of China, noticing that "nothing on this scale or speed has been witnessed before in history."

For the rest of the world, however, there is still no consensus regarding China's rise. David Lampton, a leading China scholar, once observed that "China’s sustained, rapid growth and the accumulated changes...had

\footnotetext{
3 “Why Has WIC Chosen Wuzhen?” World Internet Conference, http://www.wuzhenwic.org/2016-11/11/c_60783.htm

${ }^{4}$ For data about China, see http://data.worldbank.org/country/china

${ }^{5}$ Council on Foreign Relations, “The Rise of China and the Interests of the U.S.,” The Ripon Forum, Volume 41, No. 1, April/May 2007.

${ }^{6}$ Edward Luce, “The Changing of the Global Economic Guard,” The Atlantic, April 29, 2017.
} 
so exceeded all modest and hedged expectations that the rest of the world began to ask itself what a rapid increase in Chinese comprehensive power meant for its own economic competitiveness and military security and what opportunities and dangers might be embedded within this success."7 China's rise especially has created hot debates in the West, with the United States being the most concerned country. While many people in the United States welcomed the rise of China as a great opportunity to further integrate China into the global economy and transform China into a "responsible stakeholder" in the international system, others regarded China's rise as a challenge, if not a threat, to America's global leadership. As one scholar succinctly summarized, China's rise created some open questions: "Will China overthrow the existing order or become a part of it? And what, if anything, can the United States do to maintain its position as China rises?”8

It was against this background that the concept of "soft power" became prominent in China's political discourse. The debate between the "China opportunity" thesis and "China threat" thesis made Chinese policy makers and leading intellectuals aware that China must project a non-confrontational, friendly image abroad to dismiss concerns about China's rise. In pursuing this goal, the Chinese quickly realized the usefulness of soft power in forging their nation's international image.

The term "soft power" was originally coined in 1990 by Joseph Nye, a former U.S. defense official who later became a professor at Harvard University. Nye conceived the soft power idea to argue that the United States, despite its relative decline in economic and military power in the 1970s, still enjoyed power and influence around the world due to the superiority of its cultural values. ${ }^{9}$ Later, Nye elaborated on this concept, arguing that soft power is crucial in today's world politics:

Soft power rests on the ability to shape the preferences of others... [It] is the ability to get what you want through attraction rather than coercion or payments. It arises from the attractiveness of a country's culture, political ideas, and policies. When our policies are seen as legitimate in the eyes of others, our soft power is enhanced. ${ }^{10}$

Understandably, the idea that a country can get what it wants through appeal and attraction rather than hard power including coercion and threat easily got Chinese policy makers and intellectuals interested. It has been largely accepted that the first Chinese scholar who published on soft power was Wang Huning, a leading political theorist and a current member of the CCP’s Politburo. In his 1993 article, Wang argued that the trend of international politics now required a country to "develop its soft power as a strategic priority.” Wang emphasized a country's culture as its main source of soft power, asserting that a country with an admirable culture and value system would inspire others to follow. While recognizing that the Chinese civilization had already spread to other nations over a course of few thousand years, Wang pointed out that the only way of building up China's soft power was to constantly reinvigorate China's core cultural values. ${ }^{11}$

After Wang's article, the debate over soft power increasingly became popular in China, as scholars, journalists and policy-makers realized the strategic significance of soft power for China's rise as a global power. Although Nye's concept of soft power has been subjected to all kinds of criticism in China, various Chinese

\footnotetext{
${ }^{7}$ David Lampton, Three Faces of Chinese Power: Might, Money, and Minds (Berkeley, CA: University of California Press, 2008), pp. 3-4.

${ }^{8}$ G. John Ikenberry, “The Rise of China and The Future of the West,” Foreign Affairs, January/February 2008, Vol. 87, Issue 1, p. 23

9 Joseph Nye, Bound to Lead: The Changing Nature of American Power (New York: Basic Books, 1990).

${ }^{10}$ Nye, Soft Power: The Means to Success in World Politics (New York: Public Affairs, 2004), p. XI.

11 Wang Huning, "Zuowei guojiashili de wenhua: ruanquanli" [Culture as National Power: Soft Power], Journal of Fudan University, No. 3, 1993, pp. 91-96.
} 
schools tend to agree that culture should become the core source for China's soft power. ${ }^{12}$ In fact, there is a consensus that the lack of a set of core culture values that can appeal to other nations is actually blocking China's rise in the world. ${ }^{13}$

The Chinese leadership needed little convincing to take the building of culture values seriously. Chinese president Jiang Zemin urged the nation to build "socialist culture with Chinese characteristics" at the $15^{\text {th }}$ CCP Congress in $1997 .{ }^{14}$ In 2001, the Central Committee of CCP issued "The Program for Improving Civic Morality" which laid out a plan to construct "socialist spiritual civilization” combining Chinese traditional values with socialist core values. ${ }^{15}$ At the 16th CCP Congress in 2002, Jiang further elaborated on the importance of culture:

To build a well-off society in an all-round way calls for major efforts to develop socialist culture and spiritual civilization. In the present-day world, culture is interactive with economic and political activities and its status and functions are becoming more and more outstanding in the competition in overall national strength. The power of culture is deeply rooted in the vitality, creativity and cohesion of a nation. All Party members must fully understand the strategic significance of cultural development and make socialist culture develop and flourish. ${ }^{16}$

Liu Yunshan, the then head of the Central Propaganda Department of CCP, announced that "China must strive to become a cultural powerhouse so that socialist culture with Chinese characteristics can appeal to and inspire not only the Chinese people, but the people all around the world."17

The discourse on soft power became even more popular when the term "Beijing Consensus" was coined in 2004. The fact that China's model of development, which emphasized state control, investment in key industries and infrastructure buildings, export-oriented growth, financial self-determination, and gradualist reforms, gained popularity among the developing countries was perceived as a manifestation of China's rising soft power. ${ }^{18}$ In May 2004 during the 13th collective study session of the Politburo of the 16th CCP Central Committee, the Chinese leadership paid particular attention to the issue of soft power. The Chinese leadership decided to strengthen China's social sciences and humanities, because those disciplines were deemed essential to soft power. At the same time, it was emphasized that China's key reason of developing soft power "was not to seek global hegemony, but to earn international recognition and respect." ${ }^{\text {19 }}$ Indeed, the Chinese leadership was aware that China's rapid rise created concerns among other countries and posted a challenge to the American-led international system. China thus had to dismiss those concerns so that other countries would not create a hostile international environment that could block its future development. To achieve this goal, the

\footnotetext{
${ }^{12}$ For different Chinese schools on soft power, see Joshua Kurlantzick, Charm Offensive: How China's Soft Power Is Transforming the World (New Haven: Yale University Press, 2007); Sheng Ding, The Dragon's Hidden Wings: How China Rises with Its Soft Power (Lanham: Lexington books, 2008); Mingjiang Li, eds., Soft Power: China's Emerging Strategy in International Politics (Lanham: Lexington Books, 2009); Carola McGiffert, eds., Chinese Soft Power and Its Implications for the United States (Washington, D.C.: Center for Strategic and International Studies, 2009); Hongyi Lai and Yiyi Lu, ed., China's Soft Power and International Relations (London and New York: Routledge, 2012).

${ }^{13}$ Liu Debin, "Ruanquanlishuo de youlai he fazhan" [The Origin and Development of Soft Power], Jilin University Journal Social Sciences Edition, No. 4, July 2004.

${ }^{14}$ Jiang Zemin, "Political Report to the $15^{\text {th }}$ CCP Congress," September 12, 1997. Full text available at http://cpc.people.com.cn

${ }^{15}$ Central Committee of CCP, “Quanmin daode jianshe shishi gangyao” [The Program for Improving Civic Morality], October 2001.

16 Jiang Zemin, “Political Report to the 16th CCP Congress,” November 8, 2002. Full text available at http://cpc.people.com.cn

${ }^{17}$ Liu Yunshan, “Gaoyang xianjin wenhua de qizhi” [Hold High the Banner of Advanced Culture], People’s Daily, December 11, 2002.

18 J.C. Ramo, The Beijing Consensus (London: Foreign Policy Centre, 2004).

19 Zhao Changmao, “Zhongguo xueyao ruanshili” [China Needs Soft Power], Outlook, No. 23, 2004.
} 
Chinese leadership not only replaced the slogan "peaceful rise” with "peaceful development," which sounded less menacing, but also used soft power to promote a positive and friendly international image of China. As Chinese Premier Wen Jiabao said, China's rise "will not stand in the way of any other country, nor pose threat to any other country, nor at the cost of any other country."20 In November 2015, Chinese President Hu Jintao brought the idea of building a harmonious society, a new domestic strategy first proposed in 2004, onto the international stage. In his address to the Asia-Pacific Economic Cooperation CEO Summit, Hu stressed that "efforts should be made to build a harmonious world with an open mind, strengthen mutual trust and expand economic and trade exchanges, hold dialogue and consultations to properly address disputes, reinforce solidarity and collaboration, maintain security and stability and achieve win-win cooperation.” By championing a "harmonious world," Hu clearly was trying to enhance China's global image. ${ }^{21}$

President Hu further called for "promoting vigorous development and prosperity of socialist culture" in his political report to the 17th CCP Congress:

In the present era, culture has become a more and more important source of national cohesion and creativity and a factor of growing significance in the competition in overall national strength....We must keep to the orientation of advanced socialist culture, bring about a new upsurge in socialist cultural development, stimulate the cultural creativity of the whole nation, and enhance culture as part of the soft power of our country....We will further publicize the fine traditions of Chinese culture and use modern means of science and technology to exploit the rich resources of our national culture....We will also strengthen international cultural exchanges to draw on the fine achievements of foreign cultures and enhance the influence of Chinese culture worldwide. ${ }^{22}$

Hu's report was followed up by a new round of debate and research of soft power in China. Meanwhile, Chinese scholars and policy-makers realized that China's soft power strategy had some deficiencies, including the lack of a more aggressive campaign to promote Chinese culture abroad. ${ }^{23}$ Accordingly, the development of tourism, among other approaches, came to be regarded as one of the most efficient ways of projecting China's soft power abroad.

China's tourist industry has been growing steadily since 1978, a result of its growing economy and middle-class. The issue of soft power, however, added another key rational for developing tourism in China. In 2006, China's 11th Five-Year Plan called for a comprehensive development of tourist industry, including integrating tourism resources, establishing new tourist management system, updating tourist infrastructures, and promoting Chinese tourism aboard. ${ }^{24}$ The Beijing Olympic Games in 2008 and the Shanghai World Expo in 2010 then became two events that not only created an even greater momentum for China's tourist industry, but also showcased China's culture and soft power aboard. Tourism then became a "strategic industry" deemed important not only to Chinese economic growth but also to its diplomacy. ${ }^{25}$

Under Chinese president Xi Jinping, promoting soft power became an even greater priority for the Chinese leadership and a crucial part of Xi's “Chinese Dream” agenda. In a speech delivered at a collective study

\footnotetext{
${ }^{20}$ Xinhua News Agency, “Peaceful Rise: Strategic Choice for China,” April 25, 2004.

${ }^{21}$ Ministry of Foreign Affairs of the People’s Republic of China, "Hu Jintao Address the APEC CEO Summit," November 18, 2005.

${ }^{22}$ Hu Jintao, “Political Report to the 17th CCP Congress,” October 25, 2007. Full text available at http://cpc.people.com.cn

${ }^{23}$ For example, see Peking University Soft Power Project, "What Are the Deficiencies of China’s Soft Power?” September 16, 2009. http://theory.people.com.cn/GB/166866/166886/10068388.html. Joseph Nye also argued that China's soft power still had a long way to go. See Nye, “The Rise of China’s Soft Power,” Wall Street Journal Asia, December 29, 2005.

${ }^{24}$ For the full text of $11^{\text {th }}$ Five-Year Plan, see http://www.gov.cn/gongbao/content/2006/content_268766.htm

${ }^{25}$ Lü Benxun, “Zhongguo lüyou qiangguo zhilu: hugu yu zhanwang” [The Path of China’s Tourism Power Strategy: Retrospect and Prospect], Tourism Research, Vol. 4, No. 2, 2012, pp. 88-95.
} 
session of the CCP Politburo, Xi "vowed to promote China's cultural soft power by disseminating modern Chinese values and showing the charm of Chinese culture to the world.” Xi declared that those values should become core values of the Chinese Dream. The president said that,

China should be portrayed as a civilized country featuring rich history, ethnic unity and cultural diversity, and as an oriental power with good government, developed economy, cultural prosperity, national unity and beautiful mountains and rivers. China should also be marked as a responsible country that advocates peaceful and common development, safeguards international justice, and makes contributions to humanity, and as a socialist country which is open, amicable, promising and vibrant.... The stories of China should be well told, voices of China well spread, and characteristics of China well explained. ${ }^{26}$

Obviously, tourism would be a good way to tell the stories of China. In 2013, the State Council issued “The Outline for National Tourism and Leisure (2013-2020)," which set the ground for the redefinition of tourism development and management in China. The Chinese government now decided to "promote the healthy development of the tourism and leisure industry, and build a Chinese-style national tourism and leisure system. ${ }^{27}$ In March 22, Xi Jinping again emphasized the connection between tourism and soft power when he addressed the opening ceremony of "Tourism Year of China" in Russia. "Tourism is a bridge between civilizations and cultures, and it enhances friendship between peoples," Xi said, inviting foreign tourists to come to China to "appreciate the natural scenery, to experience Chinese culture, and to foster friendship [with] the Chinese people." 28

In summary, China's strategy to develop its soft power has increasingly emphasized the usefulness of tourism in achieving its goals. Without this background, it is hard to fully understand the story of Wuzhen. On the one hand, the timeline of Wuzhen's rise as a popular tourist destination almost coincided with China's growing interest in soft power. On the other hand, Wuzhen, one of the many ancient water towns in China's Jiangnan area, was by no means unique in terms of its history and tourist sources. Therefore, the key to understand Wuzhen's success is to understand what story Wuzhen had to tell and how the story was told.

\section{Promoting Wuzhen: From the "Land of Fish and Rice" to "Smart Town"}

Wuzhen is a typical riverine town south of the Yangtze River. It is located in the so-called Golden Triangle of Shanghai, Jiangsu, and Zhejiang, the heart of China's Jiangnan area, also known as "the land of fish and rice.” Administratively, Wuzhen belongs to Tongxiang City, Zhejiang Province. The standard promotional literature boasts Wuzhen as a 1,300-year-old water town with a civilization history of 7,000 years. ${ }^{29}$ Before Song Dynasty, the town was called different names such as Wudun, Wushu, and Wuqingzhen. Through Song and Tang Dynasties, Wuzhen gradually developed into a market town, and the name Wuzhen first appeared in history records in 813 AD. During Ming-Qing period, the Jiangnan area became the most commercialized region in China as well as a leading cultural center. Thanks to the overall development of Jiangnan and the Beijing-Hangzhou Great Canal running through it, Wuzhen enjoyed the status of a regional economic, cultural,

${ }^{26}$ Xinhua News Agency, “Xi: China to Promote Cultural Soft Power,” January 1, 2014.

27 State Council, “The Outline for National Tourism and Leisure (2013-2020)”, February 2, 2013.

http://www.gov.cn/zwgk/2013-02/18/content_2333544.htm

${ }_{28}$ China National Tourism Administration, "President Xi Jingping’s Address at the Opening Ceremony of Tourism Year of China in China”, September 14, 2015. Full text available at http://en.cnta.gov.cn

${ }_{29} 1,300$ years refer to the history of Wuzhen as a township, while 7,000 years refer to the beginning of human civilization in Wuzhen area. 
religious, and political center for centuries, before it declined in modern times due to wars, natural disasters, and the rise of Shanghai. ${ }^{30}$

Wuzhen's history did potentially qualify the town as a great tourist destination. But no one anticipated its rapid rise. When Wuzhen opened its East District (dongzha) for tourism in 2001, it attracted slightly more than a half million visitors and was simply regarded as another copycat of the then leading water town tourist site, Zhouzhuang. Among all the small towns located in the Jiangnan area, Wuzhen was only one of the many self-claimed "Venice of China," although it was named as a candidate for UNESCO's World Cultural Heritage List. Yet in 2006, Wuzhen was included in the revised List of China's Candidates for UNESCO World Cultural Heritage. In 2009, Wuzhen was named as the first PATA eco-tourism destination in Mainland China. Meanwhile, Wuzhen rebuilt its West District (xizha) and opened it for tourism in 2007. Today, Wuzhen is one of the top tourist sites in China, surpassing other water towns with nearly 10 million visitors in 2016. ${ }^{31}$

The success of Wuzhen was so influential that the term "Wuzhen Model" quickly became a buzzword in Chinese economic and cultural discourses. While the term, understandably, is fuzzy and non-exclusive, the main components of the Wuzhen Model all correspond to China's soft power strategy. First, Wuzhen has been promoted as a "typical” historical town, representing and embodying Chinese culture and traditions. Second, Wuzhen has also been promoted as a vanguard town in developing modern arts and culture. Specifically, Wuzhen has been presented as a place where the East meets the West to create new cultural ideas, thus representing future trends of development for both China and the world. Finally, the business strategies and management styles of Wuzhen as a tourist enterprise have been promoted as evidence validating the Beijing Consensus. Additionally Wuzhen's promoters have been trying to turn the town into "smart town" and a leader in cutting-edge technologies.

\section{Wuzhen and Traditional Culture}

For many Chinese, the word “Jiangnan” always invokes a nostalgic feeling about China's ancient past and finest cultural traditions. As a geographic region but more as a cultural region, Jiangnan has been idolized by many generations of poets, artists, and scholars. The crisp green hills, scenic lakes, meandering waterways, beautiful gardens, extensive rice paddies, arched bridges, and whitewashed old dwellings with high walls and elegant gables on both sides are always considered as typical Jiangnan landscape. The old Chinese saying "above there is heaven, below there are Suzhou and Hangzhou" certainly testifies to the prominence of Jiangnan in Chinese people's imagination. Economically, Jiangnan has been one of the most prosperous areas in China for centuries. Tea, silk, rice, porcelain, and rich merchants are all associated with Jiangnan. Culturally, Jiangnan has produced many of China's finest poets, artists, and scholars throughout history, not to mention the stereotyped "Jiangnan Lady" who is supposed to be particularly feminine. Overall, the idealized Jiangnan is a world of peace and harmony.

To be sure, all the images of Jiangnan are stereotyped cultural products, historically promoted by Chinese elites. But when Wuzhen was first conceived to become a modern tourist site, the planners tried to reconstruct the town in line with those images. One article promoting Wuzhen described the town as if it was a place frozen in time and history:

\footnotetext{
${ }^{30}$ Wang Jiarong, eds., Wuzhen zhi [Wuzhen Chorography] (Shanghai: Shanghai shudian, 2001), pp. 11-13; Xu Jiati, eds., Wuzhen zhanggu [A History of Wuzhen] (Shanghai: Shanghai Shehuikexueyan Press, 2003), pp. 47-49; Zhou Qiansong and Zhou Qiankang, Wuzhenshi yanjiu [The Study of the History of Wuzhen] (Hangzhou: Zhejiang University Press, 2015), pp. 22-24.

${ }^{31}$ For more statistics about Wuzhen, see http://wuzhen.com.cn
} 
Restoration is not the operative word in Wuzhen - the word, quite indisputably, is preservation. Referred to as "households sleeping on the river," each family lives above the water. For generations, people drank the river water, washed their food in it and moved about by boat. In the past, practically every family owned a boat, a necessity for transportation. Even today, the "boat garages" located beneath the houses are still well kept. ${ }^{32}$

By emphasizing Wuzhen as an effort of "preservation" rather than "restoration," the image of Wuzhen promoted here implied that the planners rediscovered rather than reconstructed Wuzhen. A piece of lost history rediscovered certainly was more attractive than a modern replica to tourists, because the pursuit of authenticity was always a good selling point in tourist industry.

However, Wuzhen was nothing like those idealized images before 1999. It was planners like Chen Xianghong who wanted to present Wuzhen as a hidden treasury rediscovered. In fact, Chen has been recognized as the chief planner of Wuzhen. During the Spring Festival of 1999, Wuzhen was badly damaged by a fire. Chen, who then was a government official of Tongxiang City, was dispatched to Wuzhen as the head of a government working group to handle reconstruction. Chen was born in Wuzhen, but he was shocked by what he saw in his hometown. According to Chen, the town was almost physically ruined, and not just because of the fire. The town still had some buildings dating back to Ming-Qing, but they were dilapidated and needed immediate maintenance. Wuzhen also had some modern residential buildings, which did not match the Ming-Qing style dwellings at all. As a result, the entire town's landscape was out of balance. In addition, the creek that ran through Wuzhen was badly polluted; certainly no one was drinking from it or washing food in it. $^{33}$

Chen sensed an opportunity to reconstruct Wuzhen based on the idealized image of Jiangnan's water town. However, his proposal was initially frustrated because as a government official he had trouble selling his idea to the Tongxiang government. Wuzhen was easily overshadowed by nearby water towns such as Zhouzhuang and Xitang that were already established as leading tourist sites. Chen realized that "Wuzhen had almost no historical heritage site well preserved." Yet the Tongxiang government eventually agreed to invest money in Chen's project because he persuaded the city that Wuzhen, if well developed as a tourist site, could both enhance Tongxiang's reputation nationally and create economic growth for the area. ${ }^{34}$

Chen worked with similar-minded people such as Ruan Yishan, a professor of architecture and urban planning, to develop a blueprint for Wuzhen's rebirth. According to Ruan, the guiding principle of the blueprint was to "restore the buildings to their original appearance (xiujiu rujiu)." In order to achieve this goal, the Wuzhen Tourism Company was founded, and Chen became the head of this state-controlled enterprise. Under his direction, Wuzhen's modern architecture were demolished. Water supply and sewage lines, power cables, and phone lines were all laid underground. Roads built with concert blocks were repaved with Ming-Qing style slab stones. All modern style windows and doors were replaced with Ming-Qing style ones, which were collected by the company from nearby villages. ${ }^{35}$ A bigger challenge was how to restore bridges that were long gone or replaced by modern ones. One example was Yingjiaqiao, a historically famous stone arch bridge built in the $18^{\text {th }}$ Century but patched up with modern concrete in the 1970s. The company took great pains to find old

\footnotetext{
32 Qian Zhang, “Balancing Tourism and Tradition,” China Daily, September 2, 2002.

33 Anonymous, "Chen Xianghong: yibiyibi huachu Wuzhen” [Chen Xianghong: Painting Wuzhen One Stroke at a Time], Business Culture, January 15, 2017, pp. 63-65.

${ }^{34}$ Wen Jie, “Chen Xianghong: Wuzhen baohu zhi mi” [Cheng Xianghong: The Myth of Preserving Wuzhen], Chengdu Daily, April 30, 2005.

35 Zhang, "Balancing Tourism and Tradition,” China Daily, September 2, 2002.
} 
stones that matched the original building materials of the bridge and restored the bridge to its Qing-style stonework. For bridges that only had ruins left, the company sent out people to search in the neighboring Jiangsu and Anhui provinces to find similar ones. Those two provinces were going through their own urbanization process, and many old villages and towns were about to be demolished. Chen's people then would offer to buy old bridges from those places and transplant the whole structure back into Wuzhen. Since those bridges were original ones from Ming-Qing's Jiangnan area, they fit better into Wuzhen's environment than modern replicas. $^{36}$

The result of all those efforts was a complete reconstruction of Wuzhen, especially Wuzhen's West District, which came to resemble the idealized image of a Jiangnan water town. While the promoters of Wuzhen continued to claim that Wuzhen was a piece of hidden history rediscovered, they also started to highly praise Chen Xianghong's unique strategy in refurbishing the town. Whether Wuzhen kept its original Ming-Qing flavors no longer mattered; what mattered now was whether Chen Xianghong's Wuzhen matched the idealized cultural image of Jiangnan water towns. "Wuzhen looks like a Chinese ink and wash painting on a misty day,” the Xinhua News Agency reported: "Clean wood-brick houses flank flagstone-paved streets and lanes. Stone arch bridges span clean waterways." ${ }^{37}$ Indeed, Chen's reconstruction of Wuzhen was celebrated as a far-sighted effort to build a sustainable industry and to "heal nature's wounds” caused by pollution from rural industrialization in the past two decades. "In addition to wondrous scenic beauty, the 1,200-year-old town is famed for its riverside wooden-structured houses with black tiles and white walls, flagstone-paved streets and lanes, and stone arch bridges over waterways," China Daily boasted: “All in traditional style.”38 While some critics argued that Wuzhen's restoration was all about developing tourism and had nothing to do with protecting historical heritage, Wuzhen's promoters countered that "no one would want to visit a real small water town that was authentic but messy; what people wanted to see was a Wuzhen that matched the ancient water town in their imagination.",39

The first major component of the Wuzhen Model, therefore, was to rebuild Wuzhen based upon the idealized image of Jiangnan water towns. Visitors are urged to enjoy life in Wuzhen, "a paradise isolated from noisy cities," staying far away from pressures of modern life. ${ }^{40}$ The essence of life in Wuzhen is supposed to be peaceful and harmonious, and the promoters of Wuzhen have urged people to do "slow tourism" there. Visitors are told that they should "experience" rather than "visit” Wuzhen in order to appreciate the peaceful and harmonious traditional life of Jiangnan China. ${ }^{41}$ No doubt, peace and harmony are exactly what China wants the international community to think of China.

\section{Wuzhen as a Modern Town}

Traditional Chinese culture, however, is not the only cornerstone of Wuzhen's ambitious tourism project. After Wuzhen's initial success, Chen Xianghong quickly realized that the mere Ming-Qing style physical appearance of Wuzhen could not guarantee the town's long-term popularity as a tourist site. The reason was

\footnotetext{
${ }^{36}$ Anonymous, "Chen Xianghong: yibiyibi huachu Wuzhen” [Chen Xianghong: Painting Wuzhen One Stroke At a Time]

37 Xinhua News Agency, “Ecological Construction,” October 4, 2004.

${ }^{38}$ Editorial, 'Eco-protection Heals Nature’s Wounds,” China Daily, October 15, 2004.

${ }^{39}$ Liu Gang and Wang Lan, "Reflections on Historic Preservation and Renovation in the Development of Wuzhen's Water Town Cultural Tourism,” Time + Architecture, February 2014, p 31.

40 Shi Bai, "Water Town of Dreams," Beijing Review, May 20, 2013.

${ }^{41}$ Wu Tao, "Wuzhen manlvyou” [Slow Tourism at Wuzhen], Yangzhou Daily, September 8, 2013; Ding Xiaomin, “Wuzhen de manshiguang” [Slow Time at Wuzhen], China Rural Finance, November 2016, pp. 106-107.
} 
simple, Wuzhen was by no means a unique water town. In fact, several other neighboring water towns were already copying Wuzhen's reconstruction strategies. Chen recalled later that he was concerned about Wuzhen becoming just one of the indistinguishable water towns, and that was when he decided to promote it with more than Chinese traditional culture. ${ }^{42}$

The first idea Chen developed was to take full advantage of the cultural heritage of Mao Dun (1896-1981), which he regarded as upscale and high-end. ${ }^{43}$ Mao Dun was the pen name of Shen Yanbing, who was one of the most celebrated left-wing novelists of modern China and once served as China's Minister of Culture. Mao Dun was born in Wuzhen, and his family house was already well-preserved in the 1980s. In 1990, a memorial hall was added next to his family house. Chen decided to turn Mao Dun's cultural legacy into a tourist attraction, a move that helped situate Wuzhen into China's revolutionary narrative given Mao Dun's reputation as a left-wing writer. In 2005, Wuzhen Tourism Company announced that Wuzhen would become the permanent home for the Issuing Ceremony of the Mao Dun Literature Award, an award considered as the "Nobel" of Chinese literature. ${ }^{44}$

While Wuzhen's celebration of Mao Dun helped to highlight the town on China's modern cultural map, Chen wanted to create his own cultural icon for Wuzhen. In 2006, readers in China were suddenly bombarded with the name "Mu Xin," who was immediately celebrated as a master writer, painter, and poet on social media. Mu Xin (1927-2011) was the pen name of Sun Pu, who was born in Wuzhen and a family friend of Mao Dun. Born into an upper class family and well educated, Mu Xin, who was allegedly gay, was imprisoned during the Cultural Revolution and most of his work destroyed. In the 1980s, he migrated to the United States and became a writer and artist of some note among overseas Chinese. Before 2006, Mu Xin certainly was not a name known to most Chinese people. Chen Xianghong, however, decided to invite Mu Xin move back to Wuzhen, and offered to renovate his old family house. ${ }^{45} \mathrm{Mu}$ Xin accepted Chen’s offer and moved back to Wuzhen in 2006, the year when he published his first book in mainland China.

The so-called Mu Xin phenomena soon started, with Mu Xin being celebrated as a rediscovered master of Chinese arts and literature. While some criticized his sudden rise as a publicity stunt and disdained his works, Wuzhen skillfully appropriated Mu Xin for its own reputation as a tourist site with enriched cultural life. Unlike Mao Dun who was a mainstream icon, Mu Xin was presented as a nonconformist writer and artist who not only had deep roots in the past, but also was ahead of his own time. ${ }^{46}$ In other words, the very ambiguity of the meaning of Mu Xin catered to the Chinese ambiguity in the pursuit of modernity. Chen then decided to build a new art museum dedicated to $\mathrm{Mu}$ Xin, which was constructed as a series of concrete-form modernist cubes floating above a lake. It was immediately praised as a masterpiece. "The design is a deliberate effort to reinterpret the centuries-old urban landscape in a contemporary yet sensitive way, a welcome change from the outlandish architecture typical of other new art museums opening up across China,” one Hong Kong newspaper reported: "The design also reflects the town's traditional use of wood and masonry."47 Wuzhen, by implication,

\footnotetext{
${ }^{42}$ Chen Xianghong Interview, Phoenix Network, http://culture.ifeng.com/niandaifang/special/chenxianghong

${ }^{43}$ Chen Xianghong, "Dui lishi de chengken, ran Wuzhen jingdeqi shenshi” [Being Honest to History allows Wuzhen Endure], Jiefang Daily, August 26, 2016.

44 "Nobel Literature Award of China to be Issued in Wuzhen,” PR Newswire, July 13, 2005.

45 Interview, "Chen Xianghong: yibiyibi huachu Wuzhen"

46 Shen He, "Mu Xin Re” [Mu Xin Phenomena], Shanghai Observer, November 26, 2015.

http://www.shobserver.com/news/detail?id=7840

${ }_{47}$ Catherin Shaw, “Wuzhen’s New Art Museum Blends Local Cultural with Modern Design,” South China Morning Post, December 9, 2015.
} 
becomes a place that thoroughly blends tradition with modernity.

While Wuzhen's popularity increased steadily thanks to Mu Xin and other cultural activities, Chen Xianghong's team decided to launch a more sustained cultural offensive that would permanently transform Wuzhen into a vanguard place of arts and culture. What followed from this decision was the launch of the Wuzhen Theatre Festival, which first started in 2013 and quickly became an annual cultural event. Chen invited Huang Lei, a famous Chinese actor, to plan the festival. They decided that Wuzhen should establish an international drama festival, following the examples of the Avignon Theatre Festival in France and the Edinburgh International Festival in the United Kingdom. The 2013 festival invited Chinese and foreign artists, presenting dramas totaling 300 hours. "It's incredible," the renowned playwright and director Stan Lai commented: "During the Wuzhen Theater Festival, artistic elements that we never thought compatible were mixed together to create a brand-new experience."

While the 2013 festival's theme was "reflection," suggesting a critical reexamination of drama and artisan values, the 2014 festival's theme became a "metamorphoses," suggesting the possibilities of transformation and experimentation. The second festival opened with one of China's most famous plays, The Green Snake, which was based on the country's best known folklore about a love story between a human and a snake-turned-fairy. The festival ended with another drama, The White Snake, which was based on the same story but produced by America's Good-man Theater. Clearly, the second festival turned Wuzhen into "a window for the East and West to see each other." ${ }^{49}$

When the third Wuzhen Theater Festival opened in 2015, Wuzhen invited even a wider variety of works from China and abroad. "The theme of this year's festival is 'transmittal.' It symbolizes the passing on of the long and glorious history of the theater," said Huang Lei: "It also represents the instrumental role theater plays in the vitalization of Chinese culture.” The third festival also sponsored many young artists to bring their shows to Wuzhen and organized a Young Theater Artist's Competition. ${ }^{50}$ The fourth festival, which opened in the fall of 2016, took as its theme "gaze beyond" and invited twenty-two plays from thirteen countries. Particularly, the festival staged a series of tribute performances to commemorate the $400^{\text {th }}$ anniversary death of both Shakespeare and Cervantes. ${ }^{51}$ From "reflection" through "metamorphoses" and "transmittal” to "gaze beyond," Wuzhen clearly was trying to establishing itself as a leading vanguard of Chinese and international art. "It has become increasingly clear that the theater festival has gone beyond just a cultural and art event," Chen Xianghong told the media at the start of the $4^{\text {th }}$ annual event. "It has become an integral part of the town's features and lifestyle." ${ }^{52}$ Boosted by the success of the Wuzhen Theater Festival, Chen further launched the Wuzhen International Contemporary Art Exhibition and an architecture biennale.

From Mao Dun to Mu Xin, from theater festivals to art exhibitions, Wuzhen clearly was trying to become a leading small town in modern and contemporary arts and culture. In other words, the Wuzhen presented here was not just an ancient town reflecting Chinese traditional culture; it was also presented as a place where China and the world encountered each other to produce new cultural trends.

\footnotetext{
48 Shi Bai, "Water Town of Dreams."

49 Han Bingbin, "Out of the Ordinary," China Daily, June 16, 2014.

${ }^{50}$ Nie Xin, “World-Class Drama Returns to Water Town,” Shanghai Daily, October 10, 2015.

51 Staff, “The $4^{\text {th }}$ Wuzhen Theater Festival," Shanghai Daily, October 12, 2016.

52 Yao Minji, "Wuzhen Sets the Stage for Countryside Tourism, “ Shanghai Daily, October 12, 2016.
} 


\section{Wuzhen as a Smart Town}

While Wuzhen's cultural offensive has been largely successful, its rapid rise as one of the most popular tourist sites in China is not entirely the result of Chen Xianghong's genius or market forces, as some promoters like to claim. On the contrary, Wuzhen's success was because the Chinese government had been involved in its planning and development from the very beginning.

To begin with, Chen Xianghong was not a businessman; he was a government official when he was put in charge of Wuzhen's reconstruction after the 1999 fire. In May 1999, the Tongxiang government committed an investment of 200 million yuan (U.S. \$ 24 million) to renovate Wuzhen, not an insignificant start-up fund for such a project. ${ }^{53}$ After the initial success of Dongzha, Chen launched the reconstruction of Xizha as Wuzhen's second stage of expansion, which eventually cost more than a billion yuan. Since the Tongxiang government did not have that kind of money, Chen had to look somewhere else. Although the Hong Kong based IDG Capital Partners became the first outsider investor, it was China CYTS Tours Holding Co Ltd,. a large state-controlled tour company that became the biggest stockholder of Wuzhen. In 2013, CYTS further bought out IDG and came to control 66\% of Wuzhen's stocks, while Tonxiang's government controlled the other $34 \%{ }^{54}$ Meanwhile, Chen continued to serve both as the head of Wuzhen company and as a government official, including the party secretary of Wuzhen. Although he later resigned his government positions, critics continued to accuse him of using public power to benefit a supposedly private business. ${ }^{55}$

The fact that Wuzhen, from the very beginning, was a market operation controlled by the government gave Chen's team great advantages. The biggest advantage, perhaps, was that Chen could use the government power to relocate all native residents of Wuzhen and reconstruct Wuzhen the way he wanted. Before the planning of Wuzhen started, Chen examined Zhouzhuang, the then leading tourist water town of China. Chen was appalled by what he saw at Zhouzhuang: lack of holistic planning and over-commercialization. While Zhouzhuang preserved many Ming-Qing style dwellings, some of them were modified to suit modern life. As a result, Zhouzhuang did not project a coordinated and harmonious landscape: a power line running right above a Ming-Qing building certainly appeared out of place for visitors. The lack of holistic planning also led to the spontaneous development of commerce. Everyone could open a small shop and sell whatever she wanted to sell. "Over-commercialization is my nightmare," Chen once commented: "Zhouzhuang’s streets were full of stores selling boiled pig feet." 56

Chen was determined to avoid Zhouzhuang's mistakes. His team decided to relocate all the native residents and rebuild Wuzhen in a holistic way so that nothing would appear out of place in this Ming-Qing style town. "Every household got 50,000 yuan (US\$6,038) for the move. They have all settled in the new buildings in the town," remembered Ruan Yishan. "So the government can now restore the old houses to their original appearance." ${ }^{, 7}$ But Chen's team did more than mere restoration. They tore down modern buildings, some of which were barely a few years old. They removed all the modern signs that might remind people that they were not stepping back into history. They completely modernized the interiors of those building to install air conditioners, flush toilets, and other modern conveniences, which annoyed critics who argued that doing so

\footnotetext{
53 Qian Zhang, "Balancing Tourism and Tradition.”

${ }^{54}$ Report, “Zhongqinglv zhi Wuzhen fazhanshi” [CYTS Develops Wuzhen], February 7, 2017.

https://xueqiu.com/6567950776/80875130

55 Chen Xianghong Interview, Phoenix Network.

56 Anonymous, "Chen Xianghong: yibiyibi huachu Wuzhen”.

${ }^{57}$ Qian Zhang, "Balancing Tourism and Tradition.”
} 
actually destroyed the interiors of historical buildings instead of preserving them. ${ }^{58}$ After the total makeover of Wuzhen, the tourism company leased back the buildings to some of the original residents to open shops and restaurants. However, since the company became the owner of the properties, the residents had to follow certain conditions. "They are required to remit most of their room fees to the company, but are allowed to keep profits from dining facilities," it was reported. "To prevent price gouging, the company sets standardized menus, but every B\&B may offer special local dishes if approved by the company." In addition, "to avoid over-commercialization and excessive duplication, the company allows only one store of a kind to open in Xizha." 59 "We set price limits on everything," Chen once bragged about his company’s micromanagement. "We even dictated how much a dish of Wuzhen chicken should weigh."60

While Wuzhen's rebirth was carefully orchestrated, the tourism company had to overcome problems that could not have been solved without government power. The biggest problem, in fact, was that many native residents refused to sell their houses to the company. An article published in 2005 quickly caused a national debate when the author reported that Chen's company forcefully relocated some residents and demolished their houses. The local government bulldozed a large area of Ming-Qing dwellings, which was actually designated early by the government as a protected historical district, without local residents signing any contract or agreement. When questioned, Chen replied that the forced demolition was legal, and "he would try to protect the interests of the people of Wuzhen but he could not guarantee that each individual's interests would be protected."61 Clearly, without government support, Chen would have had more difficulties in realizing his blueprint for Wuzhen.

Despite all the controversies, the tourism company did manage to transform Wuzhen into a top tourist site quickly, and the model of transformation was widely celebrated as a successful one. In 2014, Wuzhen further positioned itself as a leader of technological development by hosting the World Internet Conference. "We wanted a place with a booming economy that could also represent our traditional culture, a historical area that could also make the Internet more charming," explained Lu Wei, the then director of the Cyberspace Administration of China. A spokesperson of the tourism company said that Wuzhen was one of the first Chinese towns of its kind where modern telecom routes and water pipes were laid underground, "which means its appearance is ancient, but it is filled with advanced ideas inside."

The WIC conferences, which attracted prominent people around the world including the Chinese President $\mathrm{Xi}$ Jinping and CEOs of the world's leading technological companies, gave Wuzhen unprecedented exposure on the world stage. The small town did not hesitate to grasp the big opportunity, shrewdly playing up the fact that Zhejiang had the country's leading e-commerce industry including the famous Alibaba Group. ${ }^{63}$ "Once a sleepy tourist attraction, this part of Zhejiang province is so Internet-savvy that it leaves bigger cities in the shade," reported China Daily: "Free Wi-Fi, free wireless charging facilities for smartphones, digital payment facilities in restaurants, stores and guesthouses and online bike rental services have made this dream come true."

\footnotetext{
${ }^{58}$ Interview, "Chen Xianghong: yibiyibi huachu Wuzhen."

${ }^{59}$ Staff, “Rebirth of Wuzhen Brings Tourists Flocking,” Shanghai Daily, July 20, 2013.

${ }^{60}$ Interview, "Chen Xianghong: yibiyibi huachu Wuzhen."

${ }^{61}$ Cui Xiaolin, "Wuzhen chaiqian: shui de yanlei zai liutang?” [Wuzhen Demolishment: Whose Tears are flowing?] Shidaichao, January, 2005; Wen Jie, “Chen Xianghong: Wuzhen baohu zhi mi”.

62 Cao Yin, “Ancient Town Takes Advanced Net Role,” China Daily, January 5, 2015.

63 Jing Shi, "Wuzhen Clicks with Global Conference," China Daily, December 12, 2015.

${ }^{64}$ Yan Yiqi, “Ancient Town Get Smart Makeover,” China Daily, December 18, 2015.
} 
But Wuzhen did not stop at simply getting a smart makeover. Instead, it wanted to become an organic part of China's booming Internet industry. During the 2015 WIC, Wuzhen reported that the town had attracted new investments from many leading tech companies. When a gathering of the tech CEOs was reported, their youthfulness was emphasized. It was also stressed that Wuzhen, that is, China, now strived to become a leader in the development of the Internet industry. "The motto that 'not making a profit is shameful' does not apply to them," reported a think-tank. "The result of this is that new Chinese entrepreneurs think about how to change the world rather than making money, like their counterparts in Silicon Valley." 65 Tao Yongchun, the Party chief in Wuzhen, declared that "Wuzhen has attached great importance to making the town a real smart town" and "further development of the smart town will continue at a high speed.",66

With driverless cars, internet hospitals, and all kinds of other innovative gadgets, Wuzhen certainly became more famous. But from forced demolition to WIC, the reason why Wuzhen was able to move toward a smart town was government support. Like Chen Xianghong once commented, the secret of Wuzhen's success was a "market operation guided by the state." 67

\section{Wuzhen Went Abroad: The Mixed Reception of China's Venice}

Between 1999 and 2016, Wuzhen changed from an unknown and decayed small town to a famous and robust water town showcasing China's soft power. In fact, Wuzhen's development paralleled China's multi-faceted soft power offensive. First, by emphasizing its embodiment of Chinese traditional culture, Wuzhen tried to project China's value of peace and harmony to its visitors. Second, by supporting modern arts and culture, Wuzhen also positioned itself as a place of new cultural initiatives and creations. Finally, the very success of Wuzhen, especially its holistic planning with government support and transformation into a smart town, spoke volumes about the Beijing Consensus, the core of which was market economy directed by the state.

But to fully understand Wuzhen's impact on China's soft power projection, we also need to examine the perceptions and receptions of Wuzhen abroad. Here the overall international impression of Wuzhen was mixed at best. While some applauded Wuzhen as a success story, others were highly suspicious about the kind of soft power Wuzhen represented. In general, the overseas discourse on Wuzhen unfolded around two issues: authenticity and Internet censorship.

\section{Authenticity of Wuzhen: A Living Town or a Theme Park?}

Since its opening for tourism, Wuzhen quickly caught the attention of foreign visitors. In fact, Wuzhen even became the new must-see of China. "Chinese people say that if you haven't climbed the Great Wall, you haven't visited China," one English newspaper reported. "But the southern Chinese... believe that the ancient 'water town' of Wuzhen is on a par with the Great Wall -- and therefore a vital inclusion on any Sinofile's itinerary." 68

Foreign tourists were easily charmed by the beauty of Wuzhen. "It is hard to leave Wuzhen," one visitor reported: "As the evening mists start to roll in across the town, the lights go on. A luminescent glow hangs over the river, like a torchlight shining through a glass of buttermilk. Whether by accident or design, this town seems

\footnotetext{
${ }^{65}$ Zhuan Ti, “Tech Special: Young Guns Join China’s Internet Greats in Wuzhen,” China Daily, December 18, 2015.

66 Yan Yiqi, “Ancient Town Get Smart Makeover.”

67 Chen Xianghong Interview, Phoenix Network, http://culture.ifeng.com/niandaifang/special/chenxianghong

${ }^{68}$ Vanessa Mulquiney, “Float into the Past in China’s Venice,” The Daily Telegraph, October 1, 2011.
} 
to have been dropped into its watery setting by a master town planner from another galaxy." 69 For many, Wuzhen was an exotic place not just from a foreign country, but from a distant past. One reporter found Wuzhen "a cultural heritage devoid of commercial signs and souvenir stores," which was hardly true given the fact that Wuzhen was opened as a tourist site. But the reporter's excitement was real. "It's a living museum,” he claimed: "From the moment you step into the town, you are overwhelmed by a sense of discovery, of finding a town in which few from the West have set foot....You can only wonder what it was like for Marco Polo to make the journey east from Venice 700 years ago."70

One interesting theme of the foreign media's coverage of Wuzhen, especially during the first few years of its opening, was the uncritical acceptance of the claim that Wuzhen was a piece of preserved history, rather than a modern replica of an ancient water town. "Wuzhen's old buildings, an architectural symphony of stone, wood and tiles, have been preserved rather than restored, and lovingly maintained rather than tarted up," one reporter observed. "The result is a place that is a sheer joy to explore on foot. Wuzhen is still a living town, where daily life goes on as it has for the past 1000 or so years." ${ }^{, 71}$ The sense that Wuzhen was a living town was crucial here, because it gave Wuzhen an aura of authenticity in the eyes of foreign tourists. "In these days of modern theme-park re-creations of life gone by...it comes as somewhat of a surprise to discover that Wuzhen is real," one reporter mused:

Here is a "water town" as they existed in China centuries ago, opened to visitors only last year, and it is real, somehow remaining trapped in an 1850s time warp while the city surrounding it developed and modernized through the most turbulent period of Chinese history. Sure, the authorities have touched up a building here and there, maybe rebuilt a bridge, repaired the odd bit of footpath, but essentially Wuzhen is as it was 150 years ago - and, in fact, it represents a way of life stretching back for centuries. ${ }^{72}$

The consistent perception among foreign media that Wuzhen was preserved rather than reconstructed suggested that the town's marketing strategy was successful. After all, Chen's team was trying to present Wuzhen as a rediscovered historical town.

Many foreign tourists did not just believe that Wuzhen was physically preserved, they also believed that Wuzhen managed to keep its traditional way of life. "Known as the best preserved ancient town of China, Wuzhen has never changed its name, water system or lifestyle since its establishment in 872 A.D.,” claimed an American reporter, whose conclusion about Wuzhen actually revealed his ignorance of the town's history. ${ }^{73}$ Although the American's observation of Wuzhen was clearly exaggerated, the basic belief that Wuzhen has kept its traditional way of life was echoed by others. One tourist, who was impressed by Wuzhen's laid-back lifestyle of tea-drinking and Mahjong-playing, asserted that "the preservation of the historic center of Wuzhen has allowed the locals to retain a way of life that has all but disappeared in China's frenetic cities."74 Indeed, for many foreign visitors, the value of Wuzhen was highlighted by China's rapid industrialization and urbanization. "Many of the country's historic buildings continue to disappear in the name of progress but the historic town of Wuzhen is one place that has been spared these ravages," one American journalist reported. “A visit to the virtually unchanged Wuzhen is a unique experience and offers tourists the chance to imagine life in

\footnotetext{
${ }^{69}$ Graham Simmons, “Breaking Free in China,” The Sunday Mail, June 16, 2002.

${ }^{70}$ Mike Smith, “Along Byways of Ancient China,” Sunday Telegraph, May 05, 2002.

${ }^{71}$ Simmons, "Breaking Free in China,"

72 Alistair Smith, “Water Under the Bridge,” The Age, June 29, 2002.

73 D. A. Merle, "Shanghai Splendor," Standard-Speaker, April 25, 2010.

${ }^{74}$ Ewan Bell, “Backwaters of Chinese History,” Sunday Telegraph, February 18, 2007.
} 
China prior to its recent rapid industrial development.,75

In sum, many foreign visitors seemed to accept without much reflection the image of an unchanged ancient water town representing a lifestyle of peace and harmony. But some foreign visitors viewed Wuzhen with a critical eye and tried to deconstruct the images of Wuzhen put forward by Chen's team. As early as 2001, for example, one reporter speculated that "one has the feeling this is a government-sponsored model town, and that the residents are now government employees." ${ }^{, 76}$ That feeling, however, was soon substantiated by other foreign observers and created a serious challenge to Wuzhen's claim of authenticity. For example, one reporter observed that while Wuzhen did look impressive, "closer inspection reveals that the most attractive and picturesque old buildings are modern fakes.” There was nothing authentic about Wuzhen as a Ming-Qing small town, because the entire place was a modern replica with all things modern carefully hidden away from the tourists. "Phone and electrical cables are being buried underground. All waste water including household waste is being treated at a newly built plant and paving stones and bridges are being carefully repaired."77

By questioning Wuzhen's authenticity as a historical town, many foreigners argue that Wuzhen is nothing but a modern theme park. "The picturesque and ramshackle town, with its stone bridges, courtyards and wooden terraces built over the water, was 'renovated' and planted with guesthouses, hotels, restaurants and gift shops," one observer put it bluntly: " Wuzhen was reborn as a tourist theme park that now attracts up to 4,000 people a day."78 Some reporters went as far as claiming that Wuzhen was nothing but a show:

The staging is so convincing, it's no surprise that the general manager of Wuzhen, Zhou Ping, is a historian with a background in TV production and comes armed with a sponsorship deal from Shanghai Television. At times, it feels as though you've walked into The Truman Show. In Wuzhen, if you lift the wooden lid of a beautifully aged chest, you're likely to find an air-conditioning duct. People do live there, but a daytime population of actor/ workers commute in from a new suburb tucked out of sight. ${ }^{79}$

In short, the claim of authenticity was just a commercial strategy to market Wuzhen, which was not unlike other theme parks around the world.

To be sure, many foreign observers were not accusing Wuzhen of lying about its authenticity. For them, the real concern was that Wuzhen's claim of authenticity might create problems for local residents and inadvertently damage the real historical heritage in the town. Some visitors, for example, quickly noticed that local residents were forced to move out of Wuzhen. One visitor realized that Wuzhen had no "sign of that giveaway of human habitation, lines of washing flapping from upper windows, the explanation being simple: people don't live here anymore.” Indeed, local residents now became employees of the Wuzhen Tourist Company, working as shopkeepers, restaurateurs, and innkeepers. "The company looks after everything," the observer was told by a local resident: "Sweeps the streets. Collects the rubbish. I think eventually the company will take over everything.",80

In fact, what was questioned in those media reports was exactly the business model Chen Xianghong's team used to transform Wuzhen into a popular tourist site. The concern here was that the rush to preserve Wuzhen, ironically, damaged its remaining historical heritage, as the 2005 story of forced demolishment

\footnotetext{
${ }^{75}$ Karin Schumann, “Historical Town of Wuzhen Gives a Taste of Old China,” McClatchy-Tribune Business News, March 8, 2011.

76 James Caron, “Good Heavens, Suzhou Is It?” Sunday Herald, September 16, 2001.

77 Jasper Becker, “Faking It: Chinese Burn Their Bridges with the Past,” The Independent, April 2, 2004.

78 Nigel Richardson, “The Future’s Like the Past,” The Daily Telegraph, January 15, 2011.

79 Richard Caseby, “Crouching Tiger, Hideen DVD Player,” Sunday Times, February 20, 2011.

${ }^{80}$ Richardson, “The Future’s Like the Past."
} 
showed. The officials of UNESCO who managed the list of World Heritage Sites were concerned that Wuzhen's fame would cause uncontrolled tourism development, which so often would lead to "deterioration in the sites, real estate speculation and the exodus or marginalization of the local poor."81 Some were concerned that the local government would sacrifice real history for the sake of economic growth. "Authenticity is not a thing that local officials want to dwell on," one UNESCO cultural specialist said. "They see people in Zhouzhuang making money by imitating things from the past and they want to do the same.” As a result, "Centuries' worth of ancient craftsmanship have [sic] been substituted with plenty of concrete artfully hidden beneath the paint.",82

In addition, some foreign observers were concerned about the human cost of modern Wuzhen. Wuzhen was "astonishingly charming," one observer admitted. "[B]ut the fact that in Wuzhen, the original population has been entirely moved out, or...carries on as slightly mutinous extras around the boutique hotels and shops, can give one pause.” ${ }^{83}$ The New York Times also observed that the Wuzhen model disrupted local residents' lives. Some Wuzhen shopkeepers lost their old customers from nearby places, because after Chen's company took over Wuzhen, people had to buy tickets to enter the town. Even the townspeople's relatives and friends could not visit without purchasing tickets or being escorted by special guards. "Residents were forced to move. Factories were shut down. Power lines were buried underground. The canals were cleaned up. Parking lots, visitor centers and hotels were built. It was a contentious process that came with human costs.” The author blamed all these on Chen Xianghong: "Mr. Chen's approach reflects a widespread understanding of culture in China these days. Here, officials and businesspeople speak of culture more often as a commodity -- culture with a capital C -- rather than something that grows organically. "84

While the critics had a point by questioning Wuzhen's authenticity, it was clear that they were using Western standards of historical preservation to evaluate Wuzhen. But increasingly, both the Chinese and the foreign observers realized that it was not always appropriate to do so. "You can't introduce foreign concepts of conservation into China - we have to do things our own way," one Chinese official said bluntly. "The ideas of UNCESO are just too idealistic--they don't match the realities of China." ${ }^{, 85}$ Chen Xiaonghong himself once commented that it was not fair to deny residents of Wuzhen modern conveniences so that tourists could enjoy the real Ming-Qing lifestyle. ${ }^{86}$ The conflicting viewpoints prompted one author to muse:

Wuzhen is, in many ways, historically engrossing, yet also tantalizingly ambiguous. Does this place ring true in any profound way, or is it simply a monetized historic dreamscape?

“Culture is like the wind,” Mu Xin wrote. "It knows no boundaries.”

That remark hangs in the air, especially when Wuzhen is experienced in mists, light rain, or at dawn and dusk when the outlines and surfaces of the town soften exquisitely into scenes that might almost have been painted hundreds of years ago. When Wuzhen is in this condition, it seemed to me that the boundaries between history and modernity, deep culture and appliqued culture, and shopping and musing hazed into another more delicate and free-floating kind of reality. ${ }^{87}$

\footnotetext{
81 Jasper Becker, "Faking It: Chinese Burn Their Bridges with the Past.”

${ }^{82}$ Antoaneta Bezlova, "Development: China Presses for More World Heritage Listings," Global Information Network, June 24, 2004.

${ }^{83}$ Martin Woollacott, “Mass Tourism: Holidaying in the People’s Republic,” The Guardian, November 17, 2012.

${ }^{84}$ Amy Qin, “Ancient Town Finds Profitable Cultural Rebirth,” New York Times, November 10, 2016.

85 Jasper Becker, "Faking It: Chinese Burn Their Bridges with the Past.”

${ }^{86}$ Chen Xianghong Interview, Phoenix Network, http://culture.ifeng.com/niandaifang/special/chenxianghong

87 Jay Merricj, “A Tale of Two Cities Divided by Past and Present,” The Independent on Sunday, January 17, 2016.
} 
Clearly, the Wuzhen model has created new questions that cannot yet be answered satisfyingly.

\section{Wuzhen and the Internet Industry}

Like the issue of authenticity that produced many controversies, the World Internet Conference that Wuzhen hosted also created heated debates over China's Internet industry and its online censorship. As a result, Wuzhen's effort to position itself as a leading town in the Internet industry was frustrated, largely because the West did not want to fully embrace China's vision of the future of the industry. However, the conflicting viewpoints between China and the West did not produce a clear-cut picture; rather, they revealed that both China and the West faced some serious dilemmas when it came to the future development of the Internet industry.

The opening of the WIC was closely watched by foreign media, largely because China now became a leading country in the Internet industry with more than 700 million Internet users, and what happened in China would influence the global Internet industry. "With Chinese leaders emphasizing all things Internet as a major economic development strategy, and with foreign technology firms salivating over China's massive but tightly managed market," the Los Angeles Times reported, "many are looking to the conference for signposts to the future." Wuzhen, the host of the conference, also attracted immediate attention: "Why Wuzhen? What kind of city is it?" It was reported that "Wuzhen was selected as the host city because its 'Internet economy' is strong and it is a window to show Chinese history and culture.” It was also noticed that Wuzhen was located in Zhejiang province, the e-commerce center of China where internet giants such as Alibaba are headquartered. ${ }^{88}$

Understandably, many tech companies were attracted to this huge market. For example, Netflix, a major American video-streaming service, decided that China would become its most important global business. Likewise, Facebook's Mark Zackerberg studied Mandarin in order to better approach the Chinese market. "U.S. companies are going to make a Chinese play," The Washington Post reported. "Many large U.S. tech giants, from semiconductor companies to Apple, have made impressive profits in China...This is a market that makes or breaks companies.",89

Thus when the first World Internet Conference opened, it attracted roughly 1,000 Internet professionals, officials, and experts from more than 100 countries to come to Wuzhen. Founders of China's top three Internet companies Alibaba, Tencent, and Baidu as well as executives from global giants including Apple, Amazon, Google, and Facebook all joined the gala. ${ }^{90}$ The foreign guests of the conference were impressed by Wuzhen's beauty and its technological infrastructures. One visitor, for example, was particularly impressed by the face-recognition software used at Wuzhen to identify people staying in its hotels and to act as their entry pass through the gates of the attraction. Although face-recognition software had been around for a while, it was never used before at such a scale, screening hundreds of thousands people on a daily basis. Clearly, some Chinese tech companies were on their way to becomingleaders of the Internet industry. ${ }^{91}$

However, tech companies like Google and Facebook were also frustrated by what they called "China's Great Firewall,” a term coined for China's Internet policy which blocked several foreign companies' access to the Chinese market. In April 2016, the U.S. government officially classified China's Internet policy as a barrier to trade, noting that eight of the twenty-five most trafficked sites globally were blocked in China. The

\footnotetext{
${ }^{88}$ Julie Makinen, “China’s Vision for Internet,” Los Angeles Times, December 6, 2015.

${ }^{89}$ Emily Rauhala and Elizabeth Dwoskin, "For U.S. Firms, Something’s Not Clicking,” The Washington Post, December 23, 2016.

90 Xinhua News Agency, “China Focus: China Holds First World Internet Conference,” November 19, 2014.

91 Timothy Revell, “Chinese Town Uses Your Face as a Ticket,” NewScientist, November 26, 2016.
} 
American Chamber of Commerce in China reported that four out of five of its member companies experienced a negative impact on their business from Internet censorship. ${ }^{92}$ The loss of business was not the only reason why those companies complained. Some also argued that China's censorship was interfering with Internet freedom. The Reporters Without Borders organization even called for a boycott of China's hosting of the conference, labeling China as the world's No. 1 “enemy of Internet."93

From the Chinese perspective, however, the Western accusation of China's censorship of the Internet was unfair at best and hypocritical at worst. Lu Wei, director of the Cyberspace Administration of China who was dubbed as the gatekeeper of China's Internet, made this perspective clear during the first WIC. "Foreign Internet companies can come to China if they abide by the law," Lu said: "We could not allow any companies to enter China's market and make money while hurting the country.” After explaining how fake and distorted information misled capital and disrupted markets, Lu called for "respect of national sovereignty" on the Internet, arguing that countries should have the rights to regulate their own cyberspace. "We have the right to choose our friends," Lu added, "I hope everyone who comes to China will be our real friends." "94

During the second WIC meeting, Chinese President Xi Jinping officially proposed the concept of “cyberspace sovereignty.” In his keynote speech, Xi declared that the international community must "respect the right of individual countries to choose their own path to cyber development and model of cyber regulation." ${ }^{95} \mathrm{Xi}$ argued that no country should dominate cyberspace, referring to China's position that the United States had too much control over how the Internet should be managed. He added:

We should respect the right of individual countries to independently choose their own path of cyberdevelopment, model of cyberregulation and participate in international cyberspace governance on an equal footing....No country should pursue cyberhegemony, interfere in other countries' internal affairs or engage in, connive at or support cyberactivities that undermine other countries' national security. ${ }^{96}$

The Western media immediately grasped the significance of Xi's idea of cyberspace sovereignty. Clearly, China regarded the internet as a battlefield in its ideological struggle with the West and tried to become a maker rather than a follower of Internet rules and norms. In fact, many recognized that Chinese leaders also faced a dilemma in the age of information. On the one hand, internet-based technologies offered enormous potential for the country's economic growth; on the other, the free flow of information posed a threat to China's political system. Cyberspace sovereignty was China's answer to that dilemma, with the goal of balancing freedom and law and order online. ${ }^{97}$

The cyberspace sovereignty concept seemed to make some Western observers better understand China's perspective. China's call for Internet regulation had some roots in reality, which was even echoed in the United States as people were calling on tech companies to crack down on fake news. ${ }^{98}$ At the same time, Edward Snowden's revelation about the scale of global surveillance conducted over the Internet by U.S. intelligence agencies clearly "[undermined] any pretense that anyone else was really playing by the rules or any Western

\footnotetext{
92 Simon Denyer, "Behind the Firewall: How China Tamed the Internet," The Washington Post, May 23, 2016.

${ }_{93}$ Cary Huang, "Beijing Is Juggling Two Seemingly Opposing Goals,” South China Morning Post, December 17, 2015.

${ }_{94}$ Paul Mozur and Jane Perlez, “China’s Tough-Minded Web Keeper,” New York Times, December 2, 2014.

${ }^{95}$ Guest Colum, “China Has Changed Internet for World,” Lancaster Eagle Gazette, January 10, 2016;

${ }^{96}$ Gillian Wong, “China Seeks Own Sway on Internet,” The Wall Street Journal Asia, December 17, 2015.

${ }^{97}$ Cary Huang, “China: No 1 Enemy of Internet Freedom or the Global Champion of Online Technology?” South China Morning Post, December 1, 2016.

98 Emily Rauhala, “After Trump, Americans Want Facebook and Google to Vet News,” The Washington Post, November 17, 2016.
} 
claims to the moral high ground."

Clearly, the conflicting viewpoints between China and the West regarding Internet censorship will not be solved anytime soon. As a result, while the rest of the world can marvel at Wuzhen as a smart town, it is likely that China's model of the Internet industry will continue to be viewed with some suspicions. But it is also clear that the Internet will become an important tool for China's soft power. "The consequences [of Internet industry] for China in what we might call the creative economy will be substantial," one American observer argued: "the consequences in terms of China's soft power will be substantial."100 During the third WIC meeting, promoting Chinese culture and soft power via online platforms was one of the key topics. "Chinese culture and values are inherently attractive,” one Western participant observed. "The problem is articulating them well, conveying them in the right way, making sure they are well presented and delivered in an enticing manner."101 The Internet will be an excellent platform to draw attention to Chinese culture, and Wuzhen, without a doubt, will continue to play a role in the process.

\section{Conclusion}

With the rapid rise of China as a global economic and political power during the early $21^{\text {st }}$ century, Chinese leaders started to emphasize the need for China to develop its own soft power. As this article showed, the rise of Wuzhen as a popular tourist site both contributed to China's soft power projection and was helped by China's determination to tell its own story to the world.

The so-called Wuzhen Model, in a sense, is a downsized one for the Beijing Consensus because its major components correspond to the kind of soft power images that China wants to project abroad. Wuzhen claims to represent Chinese traditional culture, which stresses peace and harmony. To achieve a harmonious world, in fact, is a strategic goal China is pursuing, because China's development requires a peaceful international environment. Wuzhen also claims to be a smart town, representing a vanguard in cultural trends and cutting-edge technologies. Part of China's soft power strategy is to present itself as a country committed to innovations and creative economy. Finally, Wuzhen's success as a tourist site, well marketed and managed, but guided by the state, directly echoes the Beijing Consensus, which stresses state-controlled market economy.

At the same time, it is also clear that the Wuzhen Model has met some suspicions in the West. While Wuzhen claims to be an authentic ancient water town, some regard it as no more than a commercialized theme park. Though Wuzhen hosts the World Internet Conference which promotes China's own vision of the Internet industry, some criticize China for online censorship. Therefore, in the foreseeable future, Wuzhen clearly has more work to do if it wants to function as a window of China's soft power. Wuzhen's fate will be intertwined with China's soft power. As Shao Qiwei, the director of the China National Tourism Administration, once said, “Tourism now becomes a new culture, which is indispensable to a country's soft power growth."102

\section{References}

DING, S. (2008). The dragon's hidden wings: How China rises with its soft power. Lanham: Lexington books. Kurlantzick, J. (2007). Charm offensive: How China's soft power is transforming the world. New Haven: Yale University Press. LAI, H. Y., \& LU, Y.Y. (Eds.). (2012). China's soft power and international relations. London and New York: Routledge.

\footnotetext{
${ }^{99}$ Denyer, "Behind the Firewall: How China Tamed the Internet.”

${ }^{100}$ Ibid.

101 Hou Liqiang, “Experts: Web Has a Key Role in Promoting Chinese Culture,” China Daily, November 11, 2016.

102 Interview of Shao, March 14, 2011, http://www.cnta.gov.cn/xxfb/jdxwnew2/201506/t20150625_460443.shtml
} 
Lampton, D. (2008). Three faces of Chinese power: Might, money, and minds. Berkeley, CA: University of California Press. LI, M. J. (Eds.). (2009). Soft power: China's emerging strategy in international politics. Lanham: Lexington Books.

LIU, D. B. (2004). Ruanquanlishuo de youlai he fazhan [The Origin and Development of Soft Power]. Jilin University Journal Social Sciences Edition, (4).

McGiffert, C. (Eds.). (2009). Chinese soft power and its implications for the United States. Washington, D.C.: Center for Strategic and International Studies.

Nye, Joseph. (2004). Soft power: The means to success in world politics. New York: Public Affairs.

Ramo, J. C. (2004). The Beijing consensus. London: Foreign Policy Centre.

WANG, H. N. (1993). Zuowei guojiashili de wenhua: ruanquanli [Culture as National Power: Soft Power]. Journal of Fudan University, (3).

WANG, J. R. (Eds.). (2001). Wuzhen zhi [Wuzhen Chorography]. Shanghai: Shanghai ShuDian.

XU, J. T. (Eds.). (2003). Wuzhen zhanggu [A History of Wuzhen]. Shanghai: Shanghai Shehuikexueyan Press.

ZHOU, Q. S., \& ZHOU, Q. K. (2015). Wuzhenshi yanjiu [The Study of the History of Wuzhen]. Hangzhou: Zhejiang University Press. 